\title{
Effectiveness of land cultivation to control pests and diseases and increasing yield of shallots
}

\author{
Ni Made Delly Resiani*, I Wayan Sunanjaya, and I Made Rai Yasa \\ Assessment Institute for Agricultural Technology Bali, 80222, Indonesia
}

\begin{abstract}
Pests and diseases are one of the obstacles in increasing production and productivity of shallots. The study was conducted in Subak Rejasa Klod, Rejasa Village, Penebel District, Tabanan Regency - Bali Province. Research was conducted in JuneNovember 2019, using a split plot randomized block design. The main plot is shallot varieties $(\mathrm{V})$ and the subplot of the technical culture innovation $(\mathrm{P})$. The main plot $(\mathrm{V})$ consists of 2 treatment shallots namely Bali Karet (V1) and Lokal Tabanan (V2) and the plot consisting of 3 treatment of technical culture namely existing (P1); improvement (P2); and introduction (P3). Data on growth components and crop yields are analyzed using diversity analysis and continued with the DMRT test. Analysis of farming businesses was analyzed using $\mathrm{B} / \mathrm{C}$ ratio and $\mathrm{MBCR}$ analysis. The results showed that Spodopthera exigua and Altenaria porri at V1 are lower than V2. The highest dry weight per hectare was obtained in the Bali Karet (V1) of 20,89 tons/ha. Introduction technology (P3) is the best innovation of dry weight-weight producing per hectare on irrigation land.. The value of $\mathrm{B} / \mathrm{C}$ ratio and MBCR is 1.73 and 3.06 for introduction technology. It was concluded that introduction technology was effective as innovation of pest controllers and main diseases and were able to improve the yield of the Bali Karet variety on irrigation land.
\end{abstract}

\section{Introduction}

Shallots (Allium Cepa Var.Agregatum) are one of the horticulture commodities that are consumed fresh [1] and in processed product [2,3]. Shallots contain carbohydrates, vitamins $\mathrm{A}, \mathrm{B}$, and C [4]. According to Basuki [5], the production of shallots is quite hight every year, but it is still not enough to meet the needs of consumers so the needs to import. The opportunity to develop shallots planting area is relatively wide as market demand tends to increase [6]. Increasing production and improving quality of shallots could be done by using of the right varieties, applying proper fertilization, using appropriate and sufficient pesticides [7] and using mulch as a cultivation technique [8].

\footnotetext{
* Corresponding author: dellyresiani67@gmail.com
} 
According to data from the Ministry of Agriculture of the Republic of Indonesia [9], the cultivation of shallots in the province of Bali face many obstacles, which was shown by a decline in production of $14.61 \%$ from 11,884 tons to 10,147 tons in $2014-2015$. In the period of 2015-2020 productivity of shallots fluctuative, between 12.26 and 14.97 tons of ha-1 [10]. This decline caused by pest and disease.

Based on the above conditions, the development of shallots is needed. The development of shallots on irrigation land is a choice to support these conditions. Tabanan Regency was one of the shallots producing areas in the province of Bali decades in 1970 to $1990 \mathrm{~s}$, especially in Penebel sub-districts. However, after the 1990s until now the cultivation of shallot farmers was pressed by other horticultural commodities [11]. Farmers planting shallots in a limited area. One of the factors causing the condition is that the presence of pest attacks and diseases supported by the lack of application of technical culture technology. Based on the results of the focus discussion group, pests and dominant diseases that attacked shallots on irrigation land in Tabanan regency were attacks of caterpillar Spodopthera exigua and trotol diseases Alternaria porri.

Until now, efforts to control pests and diseases are still on the use of insecticides intensively with high doses. Jalal et al. [12], state that the yield losses due to A. porri (Ellis) attack ranged from 2.5 to 87.8 percent. According to Georghious and Saito [13], the cost to control pest and disease can reach $30-50 \%$ of the total production costs per hectare. In addition, the insecticide application also has a risk of loss of organisms instead of targets such as natural enemies and causes pest insect resistance to insecticides. Hence, it is necessary to get alternatives methods to control pest and diseases that attack shallot plants.

Improving culture technology is one of the efforts that can be developed to control pest and improve sustainable land productivity. Plant maintenance or good pest control with a combination of technical culture, including watering, fertilization, pest and diseases control and growing media replacement can increase plant resistance. Indirectly, good technical culture can monitor the existence of pests and diseases early. Based on these conditions, this experiment was done to determine the effectiveness of technical culture in controlling pests and diseases in two shallots varieties on irrigation land.

\section{Methods}

\subsection{Place and time}

The research was conducted in Subak Rejasa, Rejasa Klod Village, Penebel District, Tabanan Regency, Bali Province. The research period was between June-November 2019.

\subsection{Materials}

The materials used in this study was two varieties of shallots (Bali karet and Lokal Tabanan), organic fertilizers, inorganic fertilizers (NPK and ZA), dolomite, biological agents Beauveria bassiana, Metarizhium, and Trichoderma sp., straw mulch, black silver mulch, water. 


\subsection{Source of shallots and biological agensia}

Bali Karet variety was obtained from farmers in Songan Village, Kintamani-Bangli, while the Lokal Tabanan was obtained from farmers who have been planting shallots on their land for generations. B. bassiana, Metarizhium. and Trichoderma sp obtained from the Laboratory of Biological and Vegetable Pesticides, Plantation Plant Protection Laboratory, Department of Food Crops, Horticulture and Plantation, Bali Province.

\subsection{Experimental design}

The study used a split-plot randomized block design consisting of main plots and sub-plots. The main plot consisted of shallot varieties (V) i.e. Bali Karet (V1) and Lokal Tabanan (V2). Sub-plots consist of 3 technical culture cultivation : (P) including existing (P1); improvement $(\mathrm{P} 2)$, and introduction technology $(\mathrm{P} 3)$. Thus there are 6 (six) treatment combinations namely V1P1; V1P2; V1P3; V2P1; V2P2; and V2P3. Each treatment was repeated 10 times with treatment plot area was $200 \mathrm{~m} 2$ and the number of plants observed was 120 plants.

\subsection{Treatment components}

The difference between these three technologies is land cultivation. The existing technology farmers did not cultivate the land prior shallot planting, while in the improved technology shallots was planted on simple cultivated beds. In the introduced technology is the technology, the land was cultivated properly before planting. The beds were made as wide as $120 \mathrm{~cm}$ with the length according to the land, the distance between the beds was 50 $\mathrm{cm}$. Drainage ditch of $40 \mathrm{~cm}$ depth was made to avoid puddles of water. The planting space was $20 \mathrm{X} 20 \mathrm{~cm}$. Basic fertilization was applied at the planting date. Weeding is done manually by pulling weeds to avoid competition for nutrients from the soil. Pest control is carried out using an integrated pest management (IPM) approach. Harvesting was done at 60 days after planting, as $75 \%$ of the upper leaves turn yellow and fall.

\subsection{Observation parameters}

The data collected were maximum plant height, maximum number of leaves, number of bulbs per clump, tuber diameter per clump, wet weight per plant, wet weight per hectare, dry weight per plant, dry weight per hectare, leek caterpillar population, the percentage of plants attacked by leek caterpillars $(\%)$, the percentage of plants attacked by trotol $(A$. porri) (\%), and farm business analysis (B/C analysis) and feasibility analysis of a technology using MBCR. Percentage of the attack rate was determined using the formula [14]:

$$
\mathrm{IP}=\frac{\mathrm{A}}{\mathrm{B}} \times 100 \%
$$

$\mathrm{P}=$ Percentage of leaves affected

$A=$ The number of affected leaves

$B=$ Number of leaves observed

The criteria of pest and disease attack rate were : $0=$ healthy; $1=$ very low $(>0 \%$ $\leq 10 \%) ; 2=$ low $(>10 \%-\leq 20 \%) ; 3=$ moderate $(>20 \%-\leq 40 \%) ; 4=$ height $(>40 \%-\leq 60 \%)$; and $5=$ very high $(>60 \%-100 \%)$ 
Benefit Cost Ratio (BC ratio) analysis was used to measure the feasibility of a farm, by comparing the gross revenue and the total costs incurred. Analysis of Marginal Benefit Cost Ratio (MBCR) was done to see the effect of the introduced technology to farmer income, which was done by comparing profit and marginal cost. If the value of MBCR is more than 1 , then the introduced technology was economically profitable.

\subsection{Data analysis}

Agronomic data were analyzed using analysis of variance (ANOVA) according to the design used and then tested with the 5\% DMRT test [15]. Farming business analysis is analyzed by B/C analysis) and feasibility analysis of a technology using MBCR.

\section{Result and discussion}

The main pests and diseases of shallots as well as the growth and yield of the crop are influenced by the technical culture and varieties used, both in interaction and singly. The dominant pest found during the study was the leek caterpillar (S. exigua) and the dominant disease was trotol disease (Alternaria porri). The leek caterpillar population (S. exigua) was found to vary at various ages of shallots plants. Shallot plants of the Bali Karet variety showed a lower population development of S. exigua than the Lokal Tabanan (Fig. 1).

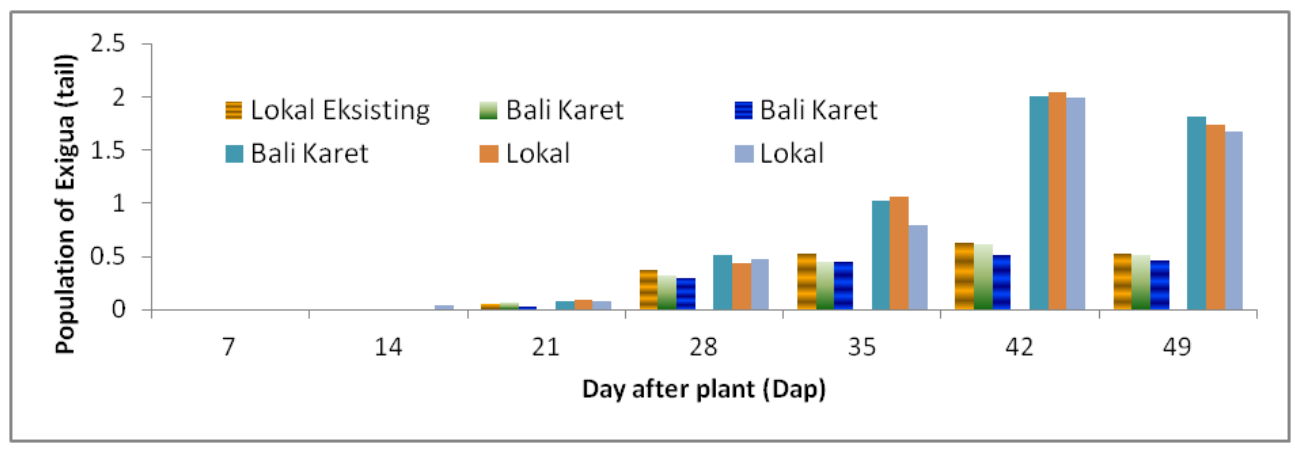

Fig. 1. Number of caterpillars of leek (S.exigua) per plant

Figure 1 shows that S.exigua caterpillars began to appear at 21 DAP and continued to increase until 42 DAP. Maximum population of S.exigua was found at 42 DAP, then tended to decrease. The S.exigua population was higher in Bali Karet variety than Lokal variety. The highest S.exigua population on Bali Karet variety was 2.04 , while on Lokal variety was 0.63. The results of this study are in line with the research of Marsadi et al. [16] which stated that the development of $S$. exigua caterpillars increased with increasing plant age in addition to being influenced by shallots plant varieties. In addition, the high number of $S$. exigua caterpillars at that age was caused by the availability of abundant food.

The percentage of S.exigua attack on shallots of Bali Karet and Lokal Tabanan showed different attacks. The attack on the Bali Karet variety was lower than Lokal Tabanan variety. S.exigua attack started at the age of 14 days after planting and reached its peak at 42 days after planting (Figure 2). This increase in attack was related to the increasing number of leaves of shallots plants that were attacked due to the large population of $S$. exigua. Judging from the criteria for the level of S.exigua attack, this attack is still classified as very low and low ranging from $(>0 \%-\leq 20 \%)$. Moekasan et al. [17] stated that the attack of $S$. exigua was classified as very low and low if the attack rate ranged between $(>$ $0 \%-\leq 20 \%)$. 


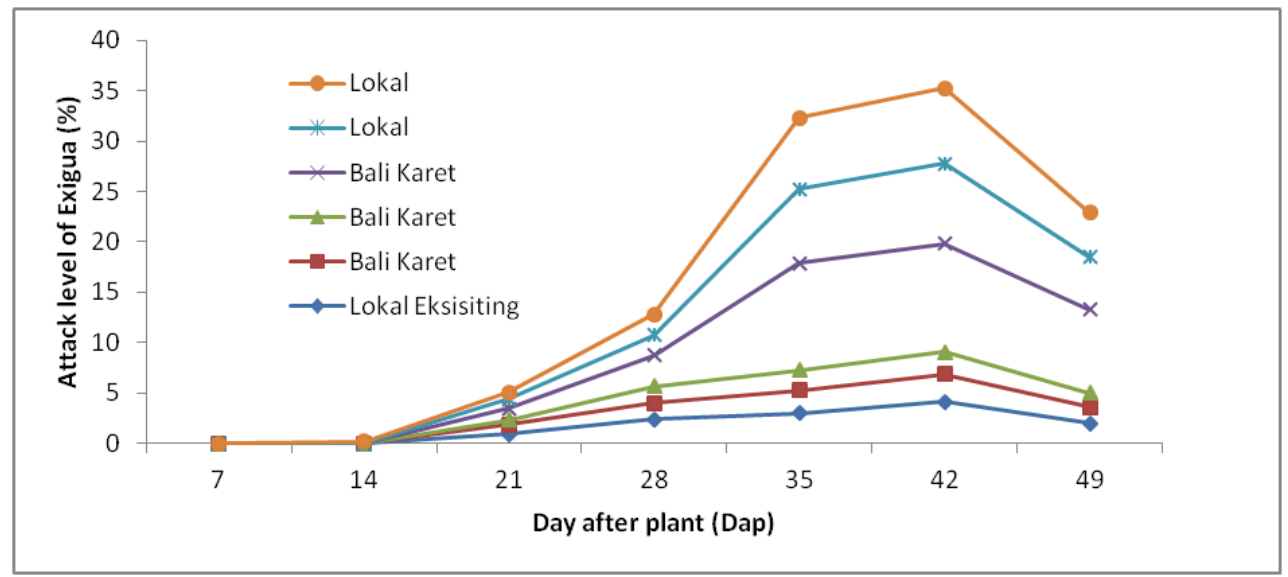

Fig. 2. Percentage of S.exigua caterpillar attacks

The results of statistical analysis showed that the treatment of varieties and technical culture had a significant (28, 35 and 42 DAP) and no significant effect ( 49 DAP) on $A$. porri attack (Table 1). Table 1 shows that the single effect of variety and technical culture cultivation varied from 28 days after planting to 49 . In 28 days after planting, varieties and technical culture had a significant effect on $A$. porri attack. The attack of $A$. porri on the Lokal Tabanan variety (14.47) was $48.72 \%$ higher than that Bali Karet (9.73). Likewise the treatment of technical culture cultivation. The existing technology showed the highest $A$. porri attack (14.22) followed by the improved (11.04) which was not significantly different from the introduction technology (11.04) (Table 1.) or in other words the improvement and introduction technology was able to suppress A.porri amounted to $28.80 \%$. Varieties and technical culture cultivation also significantly affected the attack of $A$. porri on shallots plants aged 35 days after planting (Table 1.). Attack of $A$. porri was $12.88 \%$ higher in Lokal Tabanan varieties (26.73) than Bali Karet (23.68). Likewise the cultivation of technical culture. The highest $A$. porri attack was shown in the existing technology (22.09) followed by the introduction (24.04) which was not significantly different from the improvement technology (24.47), or in other words, the introduction technology was able to suppress $A$. porri attack by $12.69 \%$. The peak of $A$. porri attack occurred in shallots plants aged 42 days after planting. $A$. porri attack had a significant effect due to differences in varieties. In the Lokal Tabanan variety, the attack of $A$. porri $(27.50)$ was $12.52 \%$ higher than Bali Karet (24.44) (Table 1). 
Table 1. The effect of a single treatment on the percentage of $A$. porri attacks

\begin{tabular}{|c|c|c|c|c|}
\hline & \multicolumn{4}{|c|}{ Percentage of $\boldsymbol{A}$. porri attacks (\%) } \\
\hline Treatment & 28 (DAP) & 35 (DAP) & 42 (DAP) & 49 (DAP) \\
\hline V1 & $9.73 \mathrm{a}$ & $23.68 \mathrm{a}$ & $24.44 \mathrm{a}$ & $8.22 \mathrm{a}$ \\
\hline V2 & $14.47 \mathrm{~b}$ & $26.73 \mathrm{~b}$ & $27.50 \mathrm{~b}$ & $9.19 \mathrm{a}$ \\
\hline CV (\%) & 25.89 & 7.42 & 6.45 & 22.29 \\
\hline LSD5\% & 2 & 1.2 & 1.13 & 1.86 \\
\hline P1 & $14.22 \mathrm{~b}$ & $27.09 \mathrm{~b}$ & $27.59 \mathrm{~b}$ & $27.76 \mathrm{~b}$ \\
\hline P2 & $11.04 \mathrm{a}$ & $24.47 \mathrm{a}$ & $25.48 \mathrm{a}$ & $25.68 \mathrm{a}$ \\
\hline P3 & $11.04 \mathrm{a}$ & $24.04 \mathrm{a}$ & $24.85 \mathrm{a}$ & $24.92 \mathrm{a}$ \\
\hline CV (\%) & 8.07 & 4.87 & 15.98 & 17.60 \\
\hline LSD5\% & 0.84 & 1.05 & 1.01 & 1.31 \\
\hline
\end{tabular}

Note: The numbers followed by the same letter are not significantly different at the $5 \%$ level of the LSD test. A1 $=$ Bali Karet Varieties; A2 $=$ Lokal Tabanan Varieties; B1 $=$ Existing Technology; B2= Improvement Technology; B3= Introduction Technology.

Varieties treatment and technical culture cultivation had a significant effect on the growth components (Table 2). Maximum plant height, maximum number of leaves and number of tubers per clump showed the interaction effect due to varietal treatment and technical culture cultivation. The highest maximum plant height was shown in the interaction treatment V1P2 (32.41) followed by V2P2 (30.90) which was not significantly different from the V1P1 treatment (26.92) and the lowest was shown in the V2P1 treatment interaction (20.13). The interaction treatment of V1P2 was able to increase the shallots plant height by $37.89 \%$ compared to V2P1 (Table 2.). The highest maximum number of leaves was shown in the V2P3 interaction treatment (23.40) which was not significantly different from the V2P2 interaction treatment (22.70). The lowest maximum leaf was shown in the V2P1 treatment interaction (16.10). V2P3 interaction treatment was able to increase the number of leaves by $31.19 \%$ compared to V2P1. The highest number of tubers per clump was shown in the V2P3 interaction treatment (12.80) which was not significantly different from the V2P2 (11.67) treatment and the lowest was in the V1P1 treatment (6.40). The V2P3 interaction treatment was able to increase the number of tubers per clump by $50 \%$ (Table 2.).The results of this study also refer to Sumarni et al. [18] who found that the development of $A$. porri disease increased with increasing plant age up to a certain age.

Table 2. Effect of treatment interactions on the mean maximum plant height, maximum number of leaves per clump, and number of tubers per clump

\begin{tabular}{|c|c|c|c|}
\hline Treatment & $\begin{array}{c}\text { Maximum plant } \\
\text { height (cm) }\end{array}$ & $\begin{array}{c}\text { Maximum number } \\
\text { of leaves (leaves) }\end{array}$ & $\begin{array}{c}\text { Number of seeds } \\
\text { per clump (seed) }\end{array}$ \\
\hline V1P1 & $26.92 \mathrm{bcd}$ & $18.17 \mathrm{ab}$ & $6.40 \mathrm{a}$ \\
\hline V1P2 & $32.41 \mathrm{e}$ & $20.53 \mathrm{bcd}$ & $6.53 \mathrm{ab}$ \\
\hline V1P3 & $24.09 \mathrm{ab}$ & $19.27 \mathrm{bc}$ & $7.24 \mathrm{abc}$ \\
\hline V2P1 & $20.13 \mathrm{a}$ & $16.10 \mathrm{a}$ & $8.20 \mathrm{bcd}$ \\
\hline V2P2 & $30.90 \mathrm{~cd}$ & $22.70 \mathrm{cde}$ & $11.67 \mathrm{bcde}$ \\
\hline V2P3 & $26.60 \mathrm{bc}$ & $23.40 \mathrm{de}$ & $12.80 \mathrm{e}$ \\
\hline CV (\%) & 13.45 & 15.30 & 21.5 \\
\hline
\end{tabular}

Note: The numbers followed by the same letter are not significantly different in the 5\% DMRT test. V1=Bali Karet Varieties; V2= Lokal Tabanan Varieties; P1= Existing Technology; P2= Improvement Technology; P3= Introduction Technology

Interaction effect of the treatments on bulb diameter, wet weight per clump and wet weight per hectare are presented in Table 3. The highest mean tuber diameter was shown in the interaction treatment V1P3 (3.10) which was not significantly different from the V1P1 (3.03) and V1P2 (2.83) treatments. The lowest tuber diameter was shown in the interaction 
treatment V2P1(1.77) (Table 2.). The highest wet weight per clump and per hectare was shown in the interaction of the V1P3 treatments (114.49 and 28.62) and the lowest was the interaction of the V2P1 treatments (36.55 and 9.14). The V1P3 treatment was able to increase the wet weight per clump and per hectare by 213.24 and $213.13 \%$ (Table 3).

Table 3. Effect of treatment on mean tuber diameter per clump and total dry plant

\begin{tabular}{|c|c|c|c|}
\hline Treatment & $\begin{array}{c}\text { Seeds diameter } \\
\text { per clump (mm) }\end{array}$ & $\begin{array}{c}\text { Wet weight } \\
\text { per clump (g) }\end{array}$ & $\begin{array}{c}\text { Wet weight } \\
\mathbf{( t / h a )}\end{array}$ \\
\hline V1P1 & $3.03 \mathrm{~d}$ & $78.92 \mathrm{~b}$ & $19.73 \mathrm{~b}$ \\
\hline $\mathrm{V} 1 \mathrm{P} 2$ & $2.83 \mathrm{~cd}$ & $98.44 \mathrm{bcd}$ & $24.61 \mathrm{bcd}$ \\
\hline $\mathrm{V} 1 \mathrm{P} 3$ & $3.10 \mathrm{~d}$ & $114.49 \mathrm{~d}$ & $28.62 \mathrm{de}$ \\
\hline $\mathrm{V} 2 \mathrm{P} 1$ & $1.77 \mathrm{a}$ & $36.55 \mathrm{a}$ & $9.14 \mathrm{a}$ \\
\hline $\mathrm{V} 2 \mathrm{P} 2$ & $2.07 \mathrm{~b}$ & $87.93 \mathrm{bc}$ & $21.98 \mathrm{bc}$ \\
\hline $\mathrm{V} 2 \mathrm{P} 3$ & $2.24 \mathrm{bc}$ & $103.38 \mathrm{~cd}$ & $25.85 \mathrm{bc}$ \\
\hline $\mathrm{CV}(\%)$ & 12.56 & 24.14 & 24.14 \\
\hline
\end{tabular}

Note: The numbers followed by the same letter are not significantly different in the 5\% DMRT test. V1=Bali Karet Varieties; V2= Lokal Tabanan Varieties; P1= Existing Technology; P2= Improvement Technology; P3= Introduction Technology.

The highest dry weight of shallots per clump and per hectare was shown in the single treatment of varieties and technical culture cultivation (Table 4.). The Bali Karet variety showed the highest dry weight per clump (83.54) and per hectare (20.89). The dry weight per clump and per hectare in the technical culture treatment was the highest in the introduction technology (89.48 and 22.37) and the lowest in the existing technology (48.30 and 12.07). The Bali Karet variety was able to increase the dry weight per clump and per hectare by 37.81 and $37.79 \%$ compared to the Lokal Tabanan variety and the introduced technical culture by 85.26 and $85.34 \%$ compared to the existing one (Table 4 ).

Table 4. The single effect of treatment on harvested dry weight per plant and per hectare

\begin{tabular}{|c|c|c|}
\hline Treatment & $\begin{array}{c}\text { Dry weight } \\
\text { per clump (g) }\end{array}$ & $\begin{array}{c}\text { Dry weight per } \\
\text { hectare (t/ha) }\end{array}$ \\
\hline V1 & $83.54 \mathrm{~b}$ & $20.89 \mathrm{~b}$ \\
\hline V2 & $60.62 \mathrm{a}$ & $15.16 \mathrm{a}$ \\
\hline CV (\%) & 9.51 & 9.51 \\
\hline LSD5\% & 1.46 & 0.37 \\
\hline P1 & $48.30 \mathrm{a}$ & $12.07 \mathrm{a}$ \\
\hline P2 & $78.46 \mathrm{~b}$ & $19.61 \mathrm{~b}$ \\
\hline P3 & $89.48 \mathrm{c}$ & $22.37 \mathrm{c}$ \\
\hline CV (\%) & 7.67 & 7.67 \\
\hline LSD 5\% & 2.37 & 0.59 \\
\hline
\end{tabular}

Note: The numbers followed by the same letter are not significantly different at the $5 \%$ level of the LSD test. V1=Bali Karet Varieties; V2= Lokal Tabanan Varieties; P1= Existing Technology; P2= Improvement Technology; P3= Introduction Technology.

The components of growth and yield of shallots vary in different environmental conditions. This incident is caused by genetic factors of the plant itself in addition to environmental factors. These environmental factors include soil, water, and microclimate. According to Sarathi [19] that plants and the environment are an inseparable unit. Plant environment is very influential on plant growth, so that different environmental conditions produce different growth in the same plant. The growth and development of shallots is strongly influenced by environmental conditions, one of which is soil conditions. Dense soil is less supportive for the growth and development of onion bulbs. 
According to Maruapey [20] plant development will be influenced by the growing environment, especially humidity and temperature around the plant. Each plant requires an optimal temperature within a certain range according to the principle of chemical reactions, as well as in the metabolic process. Anshar et al. [21] and Adi et al. [22] added that genetic factors are one of the factors causing the diversity of plant appearances. Genetics that will be expressed at a different growth phase can be expressed in various plant traits that include plant forms and functions that produce plant growth diversity. Meliala [23] states that, a variety can be said to be adaptive if it can grow well in its distribution area, with high production. Jalal et al. [12] and Saragih et al. [24] said that variety had a significant effect on the number of tillers of shallot plants. Plant height and number of leaves is an indicator of plant growth, although there is no correlation with the results of Sumarni et al. [18] added that the number of shallot cloves (saplings) was determined more by plant genetic factors than fertilization factors. The adaptation of local varieties is better than other local varieties adapted to the same environment. The alignment will visually appear in the parameters as mentioned above (Table 1-4).

\subsection{Farming Business Analysis Results}

The results of the analysis of shallots with the application of the introduction technology package show that the total cost per area is Rp. 145,150,000,-. These costs are allocated for production facilities, labor and other expenses. With this input, the yield of shallots application of the improvement technology package was $17,257 \mathrm{~kg}$, with an average price of Rp. $23,000 / \mathrm{kg}$ so that the total farmer income was Rp. 396,919,809,-. After deducting farming costs of Rp. 145,150,000, - farmers get an income of Rp. 251,769,809, -. In this farming system ratio of income to farming costs $(\mathrm{B} / \mathrm{C}$ ratio) is 1.73 , which means that it is financially profitable. The MBCR value of the improvement technology package is 3.06, which means that each additional cost of Rp. 1,000,- with the application of the improvement technology will provide an additional income of Rp. 3,060, - so that it has the potential to be developed economically (Table 5).

Table 5. Farming analysis

\begin{tabular}{|c|c|c|c|c|c|c|c|}
\hline Description & Existing & Improve-ment & $\begin{array}{c}\text { Introduc- } \\
\text { tion }\end{array}$ & Price (Rp) & Existing & Improvement & Introduction \\
\hline Spending (Rp) & & & & & 77.300 .000 & 141.750 .000 & 145.150 .000 \\
\hline Result (kg) & 8.218 & 16.041 & 17.257 & 23.000 & 189.010 .042 & 368.950 .367 & 396.919 .809 \\
\hline Profit (Rp) & & & & & 111.710 .042 & 227.200 .367 & 251.769 .809 \\
\hline B/C & & & & & 1,45 & 1,60 & 1,73 \\
\hline MBCR & & & & & & 2,79 & 3,06 \\
\hline
\end{tabular}

\section{Conclusions}

The dominant pests and diseases found attacking shallots were Spodopthera exigua and Alternaria porri. The highest attack rate is shown on the existing technology and the lowest on introduction technology. The highest dry yield of shallots is shown in the introduction technology. Innovation of introductive technology was effective as innovation of pest controllers and main diseases and were able to improve the yield of the Bali Karet shallot variety on irrigation land.

Acknowledgements. The authors thank to the Indonesian Agency for Agricultural Research and Development for providing research fund. Thanks are also conveyed to the head of ICATAD and Head of AIAT Bali. We also express our gratitude to friends who helped in carrying out this research until the writing of this paper. May all be given health in living this life. 


\section{References}

1. Firmansyah, N. Sumarni, J. Hort. 23, 4, 358-364 (2013)

2. Alfariatna, L.F. Kusmiyati, S. Anwar, J. Agro Complex. 2, 1, 19-28 (2018)

3. G. Tabor, Sci. Hortic. 240 (2018)

4. W. Sun, M.H. Shahrajabian, Q. Cheng, J. Med. Plants Res. 13, 18 (2019)

5. R.S. Basuki, J. Hort. 24, 3, 266-275 (2014)

6. S. Edi, Agroecotenia. 2, 1 (2019)

7. Resiani, M.D.D. Ni, R. Yasa, M.D. I, I.W. Sunanjaya, Sutami, P.T. Ni, K. Sukraeni, K.T. Ni, N. Widastra, N. Surateri, K.T. Ni, Laporan Akhir, Kegiatan Kajian Kultur Teknis Dan Pemanfaatan Agensia Hayati Untuk Mengendalikan Penyakit Busuk Umbi Pada Tanaman Bawang Merah, Balai Pengkajian Teknologi Pertanian Bali (2019)

8. S. Medina, D. Hariyono, J. Produksi Tanam. 7, 3 (2019)

9. Kementerian Pertanian RI, Sub Sektor Pertanian, http://www.pertanian.go.id, (2016)

10. Badan Pusat Statistik, Produktivitas Bawang Merah Menurut Provinsi, http://www.bps/go.id. (accessed on 26 April 2020)

11. M.A. Kareem, K.V.M.K. Murthy, H.A. Nadaf, M.A. Waseem, Bioinfolet. 9, 3 (2012)

12. R. Jalal, S.M. Bagheri, A. Moghimi, Iran. J. Basic Med. Sci. 14, 3 (2011)

13. G. Georghious, P. Saito, Pest Resistance to pesticides (Plenum Press, New York, 2012)

14. N.L. Suriani, Int. Res. J. Eng. IT Sci. Res. 5, 46-54 (2019)

15. K.A. Gomez, A.A. Gomez, Prosedur statistik untuk penelitian (Universitas Indonesia Press, Jakarta, 1995)

16. D. Marsadi, I.W. Supartha, A.A.A.A.S. Sunari, E-Jurnal Agroekoteknologi Trop. 6, 4 (2017)

17. Moekasan, R.S. Basuki, L. Prabaningrum, J. ort. 22, 1 (2012)

18. Sumarni, N. Rosliani, R. Basuki, Y. Hilman, J. Hort. 2, 3, 233-241 (2012)

19. P. Sarathi, ARPN J. Agric. Biol. Sci. 6, 11, 67-69 (2011)

20. Maruapey, J. Agroforestri. VII, 1 (2012)

21. Anshar, Tohari, B.H. Sunarminto, E. Sulistyaningsih, J. Agrivigor. 10, 2 (2012)

22. W.B.A. Adi, Kuswanto, A. Soegianto, J. Produksi Tanam. 1, 1 (2013)

23. B.A. Meliala, Uji Adaptasi Beberapa Varietas Bawang Merah (Allium ascalonicum) pada Musim Hujan, Skripsi (Program Studi Pemuliaan Tanaman, Departemen Budidaya Pertanian, Fakultas Pertanian, USU Medan, 2011)

24. R. Saragih, B.S.J. Damanik, B. Siagian, J. Online Agroekoteknologi. 2, 2, 712-725 (2014)

25. Suwandi, G.A. Sopha, M.P. Yufdy, J. Hort. 25, 3 (2015) 